\title{
SMILKININIO APATINIO ŽANDIKAULIO SĄNARIO, PSICHOEMOCINIO STRESO IR LAIKYSENOS SĄSAJOS
}

\author{
Simona Ulevičiūtė, Pavelas Zachovajevas, Brigita Zachovajevienė \\ Kauno kolegija
}

Raktažodžiai: laikysena, smilkininis apatinio žandikaulio sąnarys, psichoemocinis stresas.

\begin{abstract}
Santrauka
Smilkininis apatinio žandikaulio sąnarys (SAŽS) yra dažniausiai naudojamas sąnarys žmogaus kūne. SAŽS sutrikimų bent vienas iš simptomų (sutrikusị apatinio žandikaulio judesį, sąnario traškesị, raumenų sukietėjimą palpuojant) nustatomas maždaug 40-75\% suaugusių žmonių [8]. Tyrimo tikslas ịvertinti sąsajas tarp smilkininio apatinio žandikaulio sąnario, psichoemocinio streso ir laikysenos disfunkcijų. Tyrime dalyvavo 83 atsitiktinès atrankos būdu atrinkti studentai. Prichoemocinio streso vertinimas buvo atliktas naudojant suvokto streso skalę, laikysena vertinta pagal W.W. K. Hoeger laikysenos skalę. Liemens raumenų statinè ištvermè vertinta McGill testu (2002) [2], smilkininio apatinio žandikaulio sąnario funkcinè būklè vertinta naudojant liniuotę judesių amplitudei įvertinti $(\mathrm{mm})$ bei „Oxford“ skalę raumenų jẻgai ịvertinti. Psichoemocinį stresą patiria $54 \%$ merginų ir $69 \%$ vaikinų. $10 \%$ tiriamujjų turi puikią laikyseną, $22 \%$ gerą ir $68 \%$ patenkinamą. Vaikinu pilvo raumenu statinè ištvermè 1,4 karto didesné nei merginų $(\mathrm{p} \leq 0,05)$. Bendras SAŽS raumenų jègos vidurkis sudare $(3,84 \pm 0,63)$ balo. Nustatyta, kad SAŽS raumenų jèga sumažèjusi, daugiau nei puse tiriamujų patiria stresą. Pilvo raumenų statinè ištvermė susijusi su šonine liemens bei nugaros raumenų statine ištverme. SAŽS judesio nukrypimai sąlygoja kramtomujų raumenų jègą.
\end{abstract}

\section{Ivadas}

R. Pawar ir kt. [10] teigia, kad kramtymo sistema yra funkcinis kūno vienetas, kuris atsakingas už kramtymą, ryjimą ir kalbejjimą. Taip pat šiai kramtomajai sistemai priklauso smilkininis apatinis žandikaulio sąnarys (SAŽS). M.K. Murphy ir kt. teigia, kad 1980 m. buvo užfiksuota, jog SAŽS simptomus jaute $16-59 \%$ visos populiacijos ir tik 3-7\% kreipèsi ị gydymo ịstaigas, kuriems buvo nustatyta SAŽS funkcijos sutrikimai [6]. SAŽS yra dažniausiai naudojamas sąnarys žmogaus kūne. SAŽS sutrikimų bent vienas iš simptomų (sutrikusị apatinio žandikaulio judesį, sąnario traškesį, raumenų sukietėjimą palpuojant) nustatomas maždaug 40-75\% suaugusių žmonių [8]. C. Holinka, ir kt. teigia, kad tiksli miofascinio skausmo priežastis dar nèra aiški [4]. Naujausi tyrimai ịrodè, kad yra daug veiksnių, lemiančių ši skausmą - genetiniai, fiziniai ir psichiniai. Taip pat šis skausmas priklauso ir nuo gyvenimo trukmès, dèl veikiančiu psichoemocinių stresorių. Psichoemocinis stresas turi ryši su kramtomosios sistemos sutrikimais [10]. Šiandieniniame pasaulyje daugelis žmonių dèl pernelyg didelio gyvenimo tempo, tiek profesineje veikloje, tiek namuose, susiduria su psichoemociniais stresoriais, kurie gali turèti ịtakos ilgalaikiam nuovargiui ar depresijai atsirasti [9]. Tyrimai nustatè ryšį tarp stomatogeninès sistemos, raumenų sistemos ir dantų-žandikaulio-liežuvio komplekso, šie pakitimai turi itakos laikysenai [3]. Taip pat mokslininkai, tirdami SAŽS, rado statistiškai reikšmingą ryši tarp sagitalios žandikaulio padèties ir kifozinès laikysenos [12]. Manoma, kad trišakis nervas ir nervinès struktūros gali turèti tiesioginès itakos laikysenai. Vis dažniau yra tiriamas ryšys tarp fizinès ir emocinès sveikatos ir dauguma tyrimų randa sąsajas tarp šių dviejų sistemų.

Tyrimo tikslas: ịvertinti sąsajas tarp smilkininio apatinio žandikaulio sąnario, psichoemocinio streso ir laikysenos disfunkcijų.

\section{Tyrimo medžiaga ir metodai}

Tyrimas vykdytas 2016 metais Kauno kolegijos Medicinos fakulteto Reabilitacijos katedroje. Tyrime dalyvavo 83 (29 vaikinai ir 54 merginos) atsitiktinès atrankos būdu atrinkti Kauno kolegijos Medicinos fakulteto studentai. Psichoemocinio streso vertinimas atliktas naudojant suvokto streso skalę (Perceived stress scale - PSS). Tai plačiai naudojama skale patiriamam stresui įvertinti ir išsiaiškinti, kuri veikla individui ji sukelia. Klausimai sudaryti siekiant ištirti respondento požiūrị ị savo gyvenimą: ar jis nenuspè- 
jamas, nekontroliuojamas, perkrautas. Skalè turi reikšmes, kurios paverčiamos i skaitines: 0 - Niekada, 1 - Beveik niekada, 2 - Kartais, 3 - Dažnai, 4 - Labai dažnai. Stresas buvo vertinamas bendroje auditorijoje išdalinus klausimyną. Laikysenos vertinimas atliktas naudojant W.W. K. Hoeger skalę (1987). Laikysena buvo vertinama pagal šią vertinimo skalę sagitalioje ir frontalinèje plokštumoje. Šios skalès rezultatas gaunamas skaitine verte. Bendras skaitinès vertès rezultatas vertintas taip: 50-45 - laikysena puiki, 44-40 - gera, 39-30 - patenkinama, 29-20 - bloga bei $<19$ - labai bloga. Pasirinktas šis vertinimo metodas, nes laikysena ịvertinama frontalinejje ir sagitalinejje plokštumose, tai patogus, neilgai trunkantis, pigus bei informatyvus būdas. Bendra liemens raumenų statinè ištvermè vertinta McGill (2002) testu [2]. Esant gerai pilvo ir šoninių liemens raumenų statinei ištvermei, respondentas išlaiko padètį ne mažiau nei 30 sekundžių. Liemens tiesiamujų raumenų statinè ištvermé fiksuojama gera, kai respondentas išlaiko padèti ne mažiau nei $1 \mathrm{~min}$. SAŽS judesių amplitude vertinama (mm) naudojant liniuotę. Pagal judesio amplitudę galima spręsti, ar yra susidariusi raumeninè kontraktūra. SAŽS

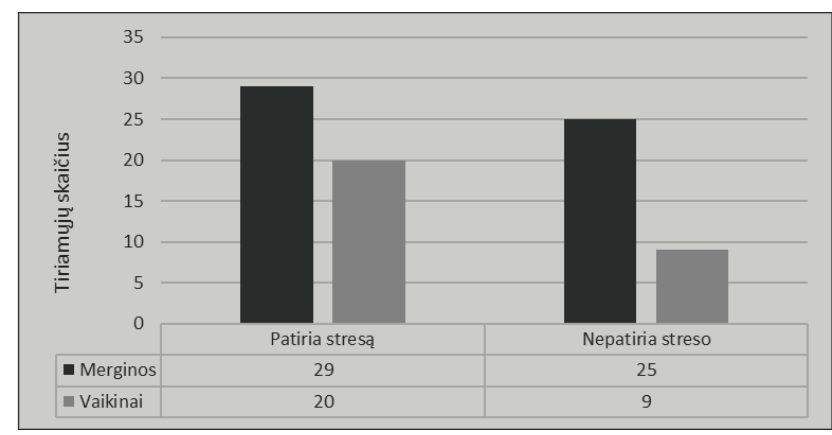

1 pav. Streso vertinimas pagal PSS skalę

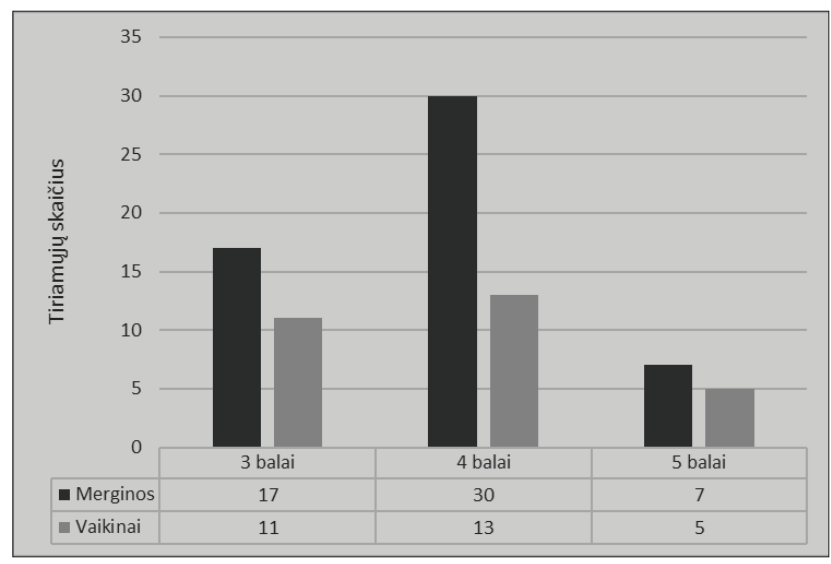

2 pav. Smilkininio apatinio žandikaulio sąnario raumenų jėga pagal „Oxford“ skalę. slydimas pirmyn testuojamas taikant pasipriešinimą po smakru į viršų, kitą ranką laikant už pakaušio ar kaklo siekiant stabilizuoti galvą. SAŽS pakèlimas vertinamas vieną ranką laikant už pakaušio ar už kaklo norint stabilizuoti kaklą, o kita ranka naudojant gumines pirštines du pirštus laikyti ant apatinių paciento dantų, pacientui pravèrus burną. Tada atliekamas pasipriešinimo judesys ị apačią [6]. Šoninis žandikaulio nukrypimas vertinamas vieną tyrejjo ranką laikant ant galvos virš SAŽS, kad būtų stabilizuota galva, kita ranka dedama ant paciento žandikaulio išilgai, burna truputi praverta - pacientas stumia žandikauli ị šoną [6]. Vertinamas maksimalus išsižiojimas, norma turètų būti 40 $60 \mathrm{~mm}$, moterų išsižiojimas mažesnis nei vyrų. Išsižiojant žiūrima, ar judesys yra simetriškas, ar daugiau pakrypsta ị kairę, ar dešinę pusę - tai rodytų raumeninį disbalansą. Matuojamas judesys nuo priekinių dantų vidurio linijos. Raumenų jèga vertinama pagal „Oxford“ manualinę raumenu jègos testavimo skalę.

Statistine duomenų analizè atlikta naudojantis ,SPSS for Windows 17.0“ ir „Microsoft Office Excel 2010“ kompiuterinèmis programomis. Kiekybiniai kintamieji pateikiami kaip aritmetinis vidurkis $(\mathrm{m})$ ir standartiné vidurkio įverčio paklaida (SEM). Funkciniams ryšiams vertinti buvo pasirinktas Spearmen'o koreliacijos koeficientas r. Tarp stebėtų kintamujų nèra ryšio jei $r=0$. Jei $0<|r| \leq 0,3$ yra labai silpnas ryšys, jei $0,3<|\mathbf{r}| \leq 0,5$ - silpnas ryšys, $0,5<|\mathrm{r}| \leq 0,7$ vidutinio stiprumo ryšys, $0,7<|\mathrm{r}| \leq 0,9$ - stiprus ryšys, o jei $0,9<|\mathrm{r}| \leq 1$ - labai stiprus ryšys. Tikrinant statistines hipotezes buvo pasirinktas 95 proc. statistinio pasikliovimo (p $<$ $0,05)$ lygmuo.

\section{Rezultatai}

Analizuodami anketinès apklausos, vertinančios suvokiamą stresą, rezultatus išsiaiškinome, jog iš visų apklaustų

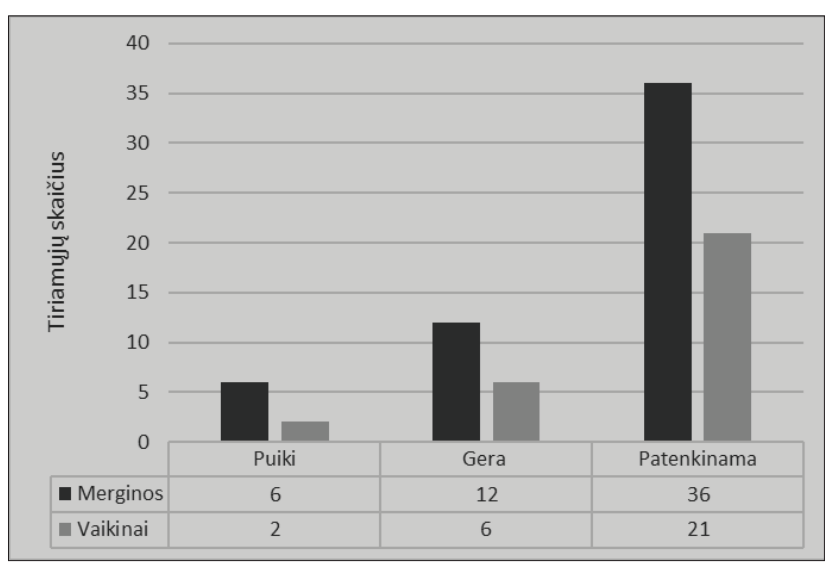

3 pav. Laikysenos vertinimas pagal W.W. K Hoeger skalę 
respondentų 54\% merginų ir $69 \%$ vaikinų patiria stresą. Nustatėme, kad daugiau nei pusė visų respondentų patiria stresą. Vaikinų patiriamo streso procentas didesnis, nei merginų (1 pav.)

Tiriant SAŽS bendrą raumenų jègą 3 balais „Oxford“ raumenų vertinimo skalèje buvo ịvertinti 28 tiriamieji, iš jų 17 merginų (31\%) ir 11 vaikinų (38\%). 43 tiriamujų bendra SAŽS raumenų jèga ịvertinta 4 balais, iš kurių 30 merginų (55\%) ir 13 vaikinų (45\%). Dvylikai tiriamujų bendra SAŽS raumenų jèga ịvertinta maksimaliai (5 balais), iš jų 7 merginoms (13\%) ir 5 vaikinams (17\%). Bendros SAŽS raumenų jẻgos įvertinimo vidurkis siekè 3,84 $\pm 0,63$ balo (2 pav.).

Analizuodami šoninio nukrypimo ị kairę duomenis merginų šoninio nukrypimo vidurkis sieké $4,23 \pm 2,26$, vaikinų 4,83 $\pm 2,45 \mathrm{~mm}$, o bendras nukrypimo vidurkis sudare $4,98 \pm 1,70 \mathrm{~mm}$. I dešinę pusę šoninio nukrypimo bendras vidurkis sudare $4,02 \pm 1,51$, merginų $3,65 \pm 1,91$, vaikinų $4,24 \pm 1,80 \mathrm{~mm}$. Vaikinų šoninis nukrypimas kairen ir dešinèn buvo didesnis nei merginų, tačiau merginų šoninis nukrypimas i kairę pusę buvo didesnis, nei i dešinę, todèl galime teigti, jog merginų dešinès pusès SAŽS raumenys buvo labiau spazmuoti, nei kairès pusès.

Nustatytas tiesinès priklausomybès silpnas statistiškai reikšmingas ryšys tarp SAŽS nukrypimo ị kairę ir bendros SAŽS raumenų jẻgos $(\mathrm{p} \leq 0,05, \mathrm{r}=0,246)$.

Analizuodami tiriamujų maksimalu išsižiojimą nustatème, jog vaikinai išsižioja $5 \mathrm{~mm}$ daugiau nei merginos ( $\mathrm{p}$ $\leq 0,05$ ). Bendras maksimalaus išsižiojimo vidurkis sudaré $46 \pm 7,37$, merginų $45 \pm 6,60$, vaikinų $50 \pm 2,26 \mathrm{~mm} .13$ tiriamujjų $(16 \%)$ iš kurių 6 merginoms $(11 \%)$ ir 7 vaikinams (24\%), nustatytas SAŽS traškesys ir skausmas judesių metu.

Ivertinus tiriamujų laikyseną paaiškejjo, jog $10 \%$ turi puikią laikyseną, $22 \%$ gerą ir $68 \%$ patenkinamą. Laikysenos vidurkiai: merginų sudare $37,96 \pm 4,24$, vaikinų $-37,4$ $\pm 3,58$, o bendras laikysenos vidurkis sieke $37,8 \pm 4,01$ balo (3 pav.). Pagal vidurkius galime spręsti, jog merginu ir vaikinų laikysenos ịvertinimai panašūs, tik merginų standartinis nuokrypis didesnis, nei vaikinų.

Išskirsčius laikysenos vertinimą pagal atskirus segmentus nustatyta, kad didžiausias procentas studentų turi nelygius pečių aukščius ( 92,5 proc.), o nelygus dubuo ir kelių hiperekstenzija atitinkamai nustatyta 86 ir 72 proc. vaikinų, tuo tarpu šių lygmenų sutrikimai nustatyti tik 24 proc. merginų. Detalus atskirų segmentų nukrypimas pagal lytis pateiktas 1 lenteleje.

Ivertinus studentų raumenų statinę ištvermę nustatyti skirtumai tarp merginų ir vaikinų. Vaikinų pilvo raumenų statinė ištvermè 1,4 karto didesnè nei merginų $(\mathrm{p} \leq 0,05)$.
Visi studentai visiškai atliko liemens raumenų statinės ištvermès testus. Nustatytas silpnas tiesinès priklausomybès ryšys tarp statinès pilvo nugaros raumenų ištvermès bei nugaros ir šoninių liemens raumenų statinès jègos $(r=0,284)$. Didejant pilvo raumenų statinei ištvermei, didejja ir liemens dešinès ir kairès pusès bei nugaros raumenų statinè ištver$\mathrm{mè}(\mathrm{p} \leq 0,05)$.

\section{Rezultatu aptarimas}

Šiame darbe buvo analizuojamos sąsajos tarp smilkininio apatinio žandikaulio sąnario funkcijos, psichoemocinio streso ir laikysenos. Vis dažniau mokslas pradeda akcentuoti, kad griaučių-raumenų sistema yra glaudžiai susijusi ne vien tik su fizine būkle, bet ir su emocine. Mūsų tyrime dalyvavę respondentai (daugiau nei pusè) nurodo, kad patiria stresą. Pihut M. su kitais autoriais tyre 25 moteris, turejjusias SAŽS funkcijos sutrikimus ir joms taikè psichoemocinio streso valdymo mokymą [11]. Tyrimo rezultatai parodè, jog sumažèjus psichoemociniam stresui gerèja SAŽS funkcija $(\mathrm{p}<0,005)$. Mūsų atliktame tyrime nenustatėme statistiškai reikšmingų sąsajų tarp SAŽS funkcijos ir patiriamo streso. Manome, kad tokius rezultatus gavome todèl, kad nedarème išsamesnès psichoemocinio streso analizės ir tiriamuosius apklausėme ir testavome vieną kartą bei nebuvo nustatyta ryškių SAŽS funkcijos sutrikimų. Be to, apklausa buvo vykdoma tiriamiesiems vienu metu, todèl tiriamieji galejo paveikti vienas kitą. Taip pat atlikę tyrimą nenustatėme statistiškai reikšmingų sąsajų tarp laikysenos ir žandikaulio jëgos M. Šidlauskienè su kolegomis nustate statistiškai reikšmingą ryṣ̨̌ tarp sagitalios smilkininio apatinio žandikaulio sąnario padèties ir kifozinès laikysenos. Nustatytas sąsajas galime paaiškinti tuo, kad tyrime dalyvavo respondentai, turintys ryškią kifozinę stuburo deformaciją [12]. M. Baiatilde su bendraautoriais ištyrė 37 tiriamuosius, kurie turejjo sutrikusią SAŽS funkciją [1]. Tyrime naudojo platformą "AM3-IST", kad sužinotų bendrą kūno spaudimo centrą ir nustaté, kuo stabilesnis SAŽS, tuo didejja laikysenos bendras stabilumas. Manome, kad tyrimo tikslumui bei statistiniam reikšmingumui turi daug itakos objektyvus kompiuterinis ištyrimas. B. Lee su autoriais tyrè asimetrinį sukandimą, kuris atsiranda dèl SAŽS raumenų nevienodo stiprumo ir trapecinio raumens [5]. Autoriai nustatė statistiškai reikšmingą ryšs tarp asimetrinio

1 lentelè. Laikysenos vertinimo atskirais segmentais rezultatai pagal lyti

\begin{tabular}{|l|l|l|l|l|}
\hline & $\begin{array}{l}\text { Nelygūs } \\
\text { pečiai }\end{array}$ & $\begin{array}{l}\text { Netiesus } \\
\text { stuburas }\end{array}$ & $\begin{array}{l}\text { Nelygus } \\
\text { dubuo }\end{array}$ & $\begin{array}{l}\text { Kelių hiper- } \\
\text { ekstenzija }\end{array}$ \\
\hline Merginos & $50(92 \%)$ & $24(44 \%)$ & $13(24 \%)$ & $13(24 \%)$ \\
\hline Vaikinai & $27(93 \%)$ & $12(41 \%)$ & $25(86 \%)$ & $21(72 \%)$ \\
\hline
\end{tabular}


sukandimo ir įvairaus trapecinio raumens viršutinès dalies ịtempimo. Mūsų atliktame tyrime radome statistiškai reikšmingą ryši tarp SAŽS nukrypimo ị kairę pusę ir bendros SAŽS raumenų jègos $(p \leq 0,05, r=0,246)$.

Pagal mūsų atlikto tyrimo rezultatus nenustatytas ryšys tarp laikysenos, liemens statinès raumenų ištvermès ir bendros SAŽS raumenų jègos ir judesių amplitudès $(p \geq 0,05)$. Apibendrinant visus tyrimo rezultatus teigiame, jog būtina kompiuterinè laikysenos vertinimo analizè, daugkartinis patiriamo streso vertinimas, kad galima būtų atlikti išsamesnius tyrimus, vertinančius streso, laikysenos bei SAŽS funkcinius ryšius.

\section{Išvados}

1. Daugiau nei puse tiriamujų patiria stresą, o bendra smilkininio apatinio žandikaulio sąnario raumenų jẻga yra sumažèjusi.

2. Daugiau nei pusei studentų nustatyta patenkinama laikysena. Vaikinų pilvo raumenų statinè ištvermé 1,4 karto didesnè nei merginų.

3. Statinè pilvo raumenų ištvermė koreliuoja su statine nugaros bei liemens šonų statine ištverme.

\section{Literatūra}

1. Baiatilde M., de Vasconcellos Vilella, O., da Silva, Hypolito GC. Posture alterations related to temporomandibular joint dysfunction. Journal of Dentistry and Oral Hygiene 2012; 4(1): $1-5$.

2. Dudonienè, V. Stuburo stabilizavimo pratimai, 2008.

3. Fjeld M, Arvidsson L, Smith H, Flatø B, Øgaard B, Larheim T. Research relationship between disease course in the temporomandibular joints and mandibular growth rotation in patients with juvenile idiopathic arthritis followed from childhood to adulthood, 2010.

4. Holinka C. Stress, emotional intelligence, and life satisfaction in college students. College Student Journal 2015; 49(2), 300-311.

5. Lee B, Lee J, Yang J, Heo K, Hwang H, Kim B, Han D. The effects of stretching exercise for upper trapezius on the asymmetric rate of bite force. Journal of Physical Therapy Science 2015; 27(7), 2159.

https:/doi.org/10.1589/jpts.27.2159

6. Magee DJ. Orthopedic physical assessment. Saunders Elsevier Pub 5th, USA, 2008; 1-9.

7. Murphy MK, MacBarb RF, Wong ME, Athanasiou KA. Temporomandibular disorders: A review of etiology, clinical management, and tissue engineering strategies. The International Journal of Oral \& Maxillofacial Implants 2013, 28(6), e393-414.

https:/doi.org/10.11607/jomi.te20

8. Park Y, Bae Y. Change of range of motion of the temporomandibular joint after correction of mild scoliosis. Journal of
Physical Therapy Science 2014; 26(8): 1157-1160.

https:/doi.org/10.1589/jpts.26.1157

9. Patil DJ, Dheer DS, Puri G, Konidena A, Dixit A, Gupta R. Psychological appraisal in temporomandibular disorders: A cross-sectional study. Indian Journal of Pain 2016; 30(1): 13. https:/doi.org/10.4103/0970-5333.173447

10. Pawar R, Gulve N, Nehete A, Dhope S, Deore D, Chinglembi N. Examination of the temporomandibular joint-A review. Journal of Applied Dental and Medical Sciences 2016; 2: 1.

11. Pihut M., Biegańska-Banaś J., Urbański P. Psychoeducation training in stress management strategies as adjunct therapy in temporomandibular joint dysfunction-preliminary study. Archives of Psychiatry and Psychotherapy 2016; 18(1): 43-47. https:/doi.org/10.12740/APP/62182

12. Sidlauskiene M, Smailiene D, Lopatiene K, Cekanauskas E, Pribuisiene R, Sidlauskas M. Relationships between malocclusion, body posture, and nasopharyngeal pathology in preorthodontic children. Medical Science Monitor : International Medical Journal of Experimental and Clinical Research 2015; 21: 1765-1773.

https:/doi.org/10.12659/MSM.893395

\section{RELATIONS BETWEEN TEMPOROMANDIBULAR JOINT FUNCTION, PSYCHO-EMOTIONAL STRESS AND POSTURE}

S. Ulevičiūtė, P. Zachovajevas, B. Zachovajevienė

Key words: posture, temporomandibular joint, psycho-emotional stress.

Summary

Temporomandibular joint (TMJ) is the most commonly used joint in the human body. TMJ disorders at least one of the symptoms (disturbed mandibular movement, joint crunching, muscles hardness) is determined approximately $40-75 \%$ of adults. The aim - to evaluate associations between temporomandibular joint function, psycho-emotional stress and posture. The study included 83 randomly selected students. Perceived stress scale was used to evaluate psycho-emotional stress, W.W.K. Hoeger visual posture evaluation method was used to evaluate students' posture McGill test was used to evaluate back muscle endurance. TMJ amplitude was evaluated employing a millimetre tape and "Oxford" manual muscle strength scale was used to evaluate temporomandibular joint muscle strength. Psycho-emotional stress experienced by $54 \%$ of girls and $69 \%$ boys. $10 \%$ of patients had excellent posture, $22 \%$ good and 68\% satisfactory. Male respondents showed to have 1.4 times higher abdominal muscle endurance than female respondents $(\mathrm{p} \leq 0.05)$. Total respondents TMJ muscle strength averaged (3.84 \pm 0.63 ) points. It was found that respondent TMJ muscles strength decreased and more than half of the patients experienced stress. Abdominal muscle static endurance associated with the side waist and back muscle endurance. TMJ motion abnormalities cause masticators muscle strength.

Correspondence to: simona.uleviciute93@gmail.com

Gauta 2016-10-02 